\title{
Letras mexicanas libanesas: Bosquejando el cedro americano
}

\author{
Mexican lebanese writtings: Sketching the American cedar
}

RODRIgo CáNOVAS

Pontificia Universidad Católica de Chile. Chile

rcanovas@uc.cl

\section{RESUMEN}

En este trabajo presentamos un panorama de la literatura mexicana centrado en la experiencia de inmigración libanesa. Primero, realizamos una breve introducción histórica sobre la inmigración y luego estudiamos los textos Las tres primeras personas de Héctor Azar, Las hojas muertas de Bárbara Jacobs, y En el verano, la tierra y Memoria de Líbano de Carlos Martínez Assad. Concluimos que estos relatos reflexionan sobre la identidad mexicanalibanesa desde las nociones de orfandad, de asimilación cultural y de alteridad.

Palabras claves: Identidad, inmigración, literatura mexicana, literatura mexicanalibanesa.

\section{ABSTRACT}

In this work we present an overview of Mexican literature centered in the Lebanese immigration experience. First there is a brief historical introduction about immigration and then we study the following texts: Las tres primeras personas by Hector Azar, Las hojas muertas by Barbara Jacobs, and En el verano, la tierra and Memoria de Libano by Carlos Martinez Assad. In conclusion, these writings make a reflection about the MexicanLebanese identity regarding the concepts of the orphan, the otherness and cultural assimilation.

Keywords: Identity, immigration, Mexican literature, Mexican-Lebanese literature. 
T ibaneses en México, pueblo milenario que se remonta a los fenicios, cuyas barcas colonizaron el Mediterráneo, otorgando además un alfabeto y un grupo de mitos que anteceden y se imbrican con el legado griego y romano. ¿Cuándo y por qué razones iniciaron su emigración desde la región del Levante hacia América? Y ya establecidos aquí, cómo han poetizado su experiencia. ¿Qué mapa, qué caligrafía han dibujado sobre el vasto territorio mexicano?

Antes de presentar el material literario sobre esta experiencia migrante libanesa, haremos una brevísima introducción histórica ${ }^{1}$. La inmigración libanesa está delimitada por serios conflictos políticos y religiosos, en el marco de la dominación imperial moderna; principalmente otomana (que abarca cuatro siglos, desde 1516 hasta 1916) y de las potencias extranjeras -recuérdese que la región de Líbano estuvo bajo mandato francés desde 1920 hasta 1943, año de la proclamación de la República.

Un inicio posible de la historia moderna de la inmigración libanesa es la instalación del territorio de Mustassarifat o Pequeño Líbano (1861-1915), a raíz de los constantes enfrentamientos entre drusos y maronitas. Esta extensión de terreno -para la población principalmente de credo maronita- abarcaba el $60 \%$ del territorio anterior, siendo la región menos fértil; lo cual generó flujos migratorios constantes hacia países vecinos y al resto del globo terráqueo.

Las olas migratorias libanesas a América ocurren mayoritariamente entre 1914 y 1932; habiendo ya antes una población representativa en Estados Unidos (en 1870 existe el barrio Nueva Siria en Nueva York). Por las leyes restrictivas de Estados Unidos, las principales opciones son Brasil, Argentina y Uruguay, que albergan en la actualidad al menos un millón y medio de descendientes de libaneses. Durante la segunda mitad del siglo XX, las oleadas migratorias continuaron. Por la guerra civil (1975-1982), que significó la muerte de 200.000 libaneses, se calcula que emigraron 800.000 personas de Líbano, alrededor de un 40\% de la población.

En el caso mexicano, los inmigrantes árabes son en su mayoría cristianos maronitas (habiendo también un grupo de cristianos ortodoxos y un pequeño grupo melquita), provenientes del Mustassarifat y de algunos puertos como Trípoli y El Batroum. Ya entre 1882 y 1889 se contaban en México 30 personas de ascendencia árabe. Hacia 1910, un censo oficial de la región de Yucatán -donde se registra una temprana presencia libanesa- registra 568 turcos (que según testimonios, correspondería a una cifra real de alrededor de 2.000). Y según el censo general realizado por las colonias árabes residentes en el país,

${ }^{1}$ Resumimos aquí los textos consultados sobre la inmigración árabe y libanesa a México (cf. Referencias). 
hacia 1948 había una población de 16.403 libaneses en México. Actualmente, de acuerdo a cifras de la ONU, se cuentan 80.000; sin embargo, la comunidad libanesa realiza un cálculo muchísimo mayor.

Los mexicanos de origen libanés han constituido una comunidad muy activa y arborescente, desde los inicios del siglo XX (ya en 1902 se constata la presencia de una Sociedad de Jóvenes Libaneses en Mérida). Sus incontables organizaciones durante el transcurso del siglo pasado, de carácter social, religioso, económico y cultural, así lo acreditan; amén de sus redes familiares amplias. Acaso coronando este espíritu de inmigrante que incluye el legado de la tierra originaria (el bled), surgen recientemente dos publicaciones que contienen la querencia libanesa en un registro histórico-cultural, onomástico y testimonial. Una es De Líbano a México (Díaz y Macluf, 1997), una maravillosa crónica sobre la experiencia migrante, ilustrada por álbumes familiares, fotos de tiendas y de celebraciones en centros sociales; más esos increíbles pasaportes en distintos idiomas y con diversas caligrafías. La otra es un Diccionario enciclopédico (Jacobs, 2000), junto a un grupo de colaboradores, que incluye un amplio registro de términos vinculados a las costumbres, la gastronomía, la historia, la lengua árabe, la presencia del Levante en México y la religión; además de un registro biográfico onomástico de miembros notables de la comunidad.

Las personas de origen libanés son considerados mexicanos desde la segunda generación; siendo un grupo que demuestra un grado de asimilación muy marcado a la sociedad mexicana global (lo cual puede fácilmente contrastarse, por ejemplo, con el grupo judío). Son mexicanos, agregando un origen levantino, que gira en torno a la imagen sagrada del cedro, árbol milenario plantado en el Génesis. Ahora bien, ¿qué registros poéticos tiene esta sensibilidad mexicanalibanesa, que ensambla naturalmente dos realidades tan diversas?

Es notable que la figura literaria de mayor prestigio de origen libanés, el poeta Jaime Sabines (1926-1999), quien en vida siempre celebró su proveniencia del poblado de Saghbine (del cual se deriva su apellido), no haya escrito algún poema alusivo a sus orígenes ${ }^{2}$. La única huella aparece en "Algo sobre la muerte del Mayor Sabines", que data de 1973, texto sobre su padre (conocido por su participación en la revolución, en las filas carrancistas), que en un verso y entre guiones, leemos: "-cedro del Líbano, robledal de Chiapas-"; para luego continuar: "te ocultas en la tierra, te remontas / a tu raíz oscura y desolada" (Sabines, 2003: 259).

\footnotetext{
${ }^{2}$ Otro ejemplo similar es el de Gabriel Zaid, de origen palestino. Ensayista, poeta, crítico y traductor nacido en 1934; su obra no ofrece marcas explícitas de carácter árabe. No obstante, al igual que Sabines, en su vida pública es clara su identidad mexicana-libanesa. ¿¿Seducidos por la lengua mexicana?
} 
Acaso este verso único (punta de iceberg) sintetice el sentimiento de un alma colectiva que hace imbricarse raíces que señalan un nuevo génesis. Alma sumativa del padre inmigrante, que yuxtapone dos orígenes, para fundar una nueva estirpe, de cedro americano.

Siendo la asimilación el rasgo distintivo de este grupo, resulta extraño que sus materias literarias sigan un movimiento más bien divergente a ese rasgo. Así, lo que se constata es el sentimiento de forasterismo del padre libanés, raíz al aire (en el relato de Bárbara Jacobs) y el acto de reminiscencia, por el cual el presente cobra su sentido en un gesto de regresión fundado en la memoria histórica (tanto en la novela como en el diario de viajes de Carlos Martínez Assad). Quizá el texto que más se detiene en la integración mexicana (vasto cuerpo que acoge sin medida a estos andantes que buscan una segunda oportunidad en estas vidas) es el de Héctor Azar, en cuanto muestra la lengua mexicana como una matriz sensorial desde la cual el inmigrante aparece trasvestido y lanzado nuevamente a un mundo local junto a su descendencia, compartiendo la sensorialidad y las ganas de vivir propias de libaneses y mexicanos.

Corpus reducido, pero suficiente para desplegar un capítulo suplementario en la literatura mexicana, la letra en falta, puesto que descentra al sujeto americano al obligarlo a remontar las escalas del Levante.

\section{LA FIESTA MEXICANA}

El primer ejercicio literario sobre la inmigración libanesa en México es realizado por Héctor Azar, en su novela biográfica Las tres primeras personas (Azar, 1977) ${ }^{3}$. Siendo eminentemente un hombre de teatro, no es extraño que componga su relato a través de cuadros o escenas fijas, que aparentan ser costumbristas pero que son intervenidas por un lenguaje celebratorio (una abigarrada escenografía) que atraviesa a los cuerpos migrantes dotándolos de visibilidad.

La obra se abre con los testimonios de la partida del bled y de las penurias del viaje de las tres personas migrantes, un gajo familiar compuesto por la hija mayor (Perla, de 11 años), Brillante (de 9 años) y Musa, el padre, hacia el año 1907. A continuación viene el cuadro dedicado a Veracruz (espacio de acogida nutricio, donde se les agasaja con cazuelas en pote de barro) y al Interoceánico

${ }^{3}$ Héctor Azar (1930-2000) fue un distinguido dramaturgo, que fundó y dirigió el Centro de Arte Dramático, CADAC. Con su obra dramática Juegos de azar obtuvo en 1973 el Premio Xavier Villaurrutia. Se suponía que su primera novela formaba parte de una trilogía sobre la experiencia de la inmigración libanesa, que no se continuó. 
(nombre del tren que lleva al grupo hacia el interior). Hasta aquí, el lector entiende que está leyendo un relato documental (incluso aparece una foto del padre y las dos niñas; supuestamente del abuelo y las tías del escribiente), que cubre el desvío migrante de USA a México (se les rechaza la entrada a las hijas), los contactos espontáneos con los libaneses del puerto veracruzano y las primeras imágenes del paisaje campestre mexicano a través de las ventanas del tren.

No obstante, ya en este viaje el mundo comienza a desordenarse en la conciencia de los personajes, apareciendo también cierto desparpajo lingüístico de una voz comunitaria: "La calle principal del pueblo que acabamos de dejar era un atajo de burros entre montañas de mierda, pedazos de carne pegados a una mesa plagada de moscas con un marco de madera y ondas de longaniza enteca haciéndose la payasa, la muy cabrona" (Azar, 1977: 40). Por supuesto que este parlamento no puede estar pronunciado por los recién llegados; siendo una acomodación hecha por una voz familiar actual (dispuesta por el nieto, nacido en este país) que va envolviendo a estos primeros paisanos en el habla coloquial mexicana.

Ya en el siguiente cuadro, entendemos que el formato documental (de registro realista) es un débil tinglado, acaso un esqueleto, sólo necesario para ser rellenado por una experiencia de extravío y asimilación, en la cual el espíritu de la lengua ilumina y traga a esos cuerpos migrantes. El capítulo se denomina "La Gare Saint-Lazare". Sin más, alguien evoca desde el presente su encuentro con un obrero español en París, quien vive con una mujer pronta a ser deportada a América. Desde la noción de distanciamiento, escuchamos la voz de la autoría -"el que esto escribe" (Azar, 1977: 45)-, quien exhibe las dificultades de su proyecto: cómo rescatar a sus parientes, cómo figurarlos, cómo apropiarse de ellos. Escuchemos: “¡Taca! ¡Taca! ¡Ta cabrón! ¡Pariente prójimo del oriente medio! ¡Deja que yo te ame como a mí mismo, pero taca!” (Azar, 1977: 51). Y más adelante continúa: “¡Deja que te corone con las tunas cardonas desde tupida nopalera altiplano y rejega y que te aguantes con el chichicaste de las rosas guadalupanas, únicas que tenemos, por ahora, en las venas y en las arterias que van a dar a nuestro corazón mezcalero y tlachicotón! ¡Salud!” (Azar, 1977: 51).

De cómo los descendientes (la tercera generación) se colocan en el lugar de los mexicanos que vieron por primera vez a esos abuelos inmigrantes, de los albures, de las risotadas, de un país que de inmediato los incluye desde la celebración lingüística de esos nombres extraños, tergiversándolos, por cierto; pero también haciéndolos transitar libremente por la primera década del siglo XX, en vísperas del Centenario. Así, frente al nombre propio de Musa, ya 
comienza el ingenio mexicano a ejercer la herida de la asimilación; único remedio a la orfandad de estos hablantes árabes (con el francés como lengua franca): "-¿Cómo Musa? Ese será nombre de hembra, no de hombre / -Oui, Musa / -Ponle Moisés y que muera el cuento / ... / -iMusa? O manso / -O menso. Tiene cara de pensil" (Azar, 1977: 48).

Los siguientes capítulos se presentan como grandes frisos lingüísticos, en los cuales se exhiben discursos sociales en sus variantes políticas y populares, de un modo festivamente paródico. Así se habla de los destinos de la nación en un lenguaje positivista altisonante (haciéndose un símil con los rasgos físicos del hombre mexicano en "Dibujando la cabeza") y se presenta a las damas de la caridad en los jardines de la Tabacalera Mexicana en un lenguaje farsesco y vociferante (en "El reparto de ropa").

Son pastiches, la mimesis de la mexicanidad de hace un siglo, ejercicios que abarcan también la escritura de una carta de don Moisés a su esposa Zaide Zenorina. ¿Qué decir, en qué formato, con qué remitente? Leemos una carta escrita en español, dictada al amanuense don José Loreto Trejo (que, de seguro, intervino el texto a nivel lexical y sintáctico), a quien le parece que la misiva es muy sentimentaloide (una interpretación local para la sensibilidad del bled). Más allá de la información del barrio donde viven (en la azotea de la casa del callejón de Manzanares) y del trabajo que ejerce (empleado en una lavandería de unos chinos); es evidente que los datos constituyen aquí un mero decorado ante la pregunta y el desafío sobre cómo escribir una historia familiar, habiendo extraviado la lengua de origen y, además, siendo ya -en el caso del escritor- un mexicano de tomo y lomo.

Y aparece también la atracción y la repulsión por el testimonio (de allí los constantes descalces entre vidas y actuaciones, entre espacios reales y decorados, entre el presente y el pasado; en fin, entre el nieto y el abuelo) y el deseo de construir un texto vanguardista, que sólo se sostenga en el concierto abigarrado de voces híbridas (letradas y populares), que sostendrían y acunarían estos seres llegados de tan lejos. Es como si la autoría los sintiera muy remotos y, sin embargo, fueran parte de su memoria íntima; entonces, lo que tiene que hacer es traducir esa experiencia interior en un lenguaje propio que sea capaz de contener las voces anteriores y del futuro. No es posible rescatarlos en su ser -de allí que presente a estas tres primeras personas de modo lateral y casi silentes-; pero sí desde su descendencia y hacerlos vibrar al ritmo del habla mexicana. Sólo el aprendizaje lingüístico rescata (y funda) el espíritu mexicano-libanés: "Sobre cada curul, un velo de tul; sobre cada hogar hay un holgazán; en los bancos de salitre, los propietarios buitres; para los trabajadores, los explotadores; lo que tenemos y no apreciamos, don 
Moisés; para la patria que añora, jugar carretas con la locomotora" (Azar, 1977: 88).

El relato toma un vuelco con la presentación de Anna Gould, condesa de Castellane, acaso el único personaje más delineado y acabado de toda la obra. Estamos en Pachuca, donde las tres primeras personas aparecen bajo el amparo de su pariente Slaimei, un libanés tórrido, mantenido de la condesa, con quien comparte los rasgos del oportunismo, despilfarro, sensorialidad y una vena privilegiada para los negocios. Los cuadros que se exhiben hasta la conclusión del texto recrean el espacio institucional provinciano de Pachuca. En "El Simulacro" asistimos a los juegos de guerra realizados en el Colegio Militar ante las autoridades, incluida Ana la chabacana, escuchando la cháchara sobre los planes del Centenario. Luego en "La Antigua Frontera" aparece la condesa con don Rómulo Luna, dueño del negocio de ese nombre, dialogando allí sobre el acontecer nacional (aquí Ana deja conectado a Musa, para pedir mercadería y venderla en las calles como varillero y juglar, junto a su hija mayor).

La siguiente escena (son cuadros sociales, exhibidos desde un lenguaje abigarrado que convierte a los personajes en actores de opereta) se denomina "Malgré Tout", donde se escenifica la disputa de Ana con la Mère Jacqueline (del Colegio del Sagrado Corazón), quien se niega a aceptar a la hija de un inmigrante como pupila. En sordina, escuchamos una ralea de frases que van retorciendo la figura de la madre superiora: "Jacqueline cangrina, purgativa, molina, repelina, tuberculina, prostatina que jamás osó ponerme [a mí, Ana, ex alumna de este colegio] corona de laureles en mis Premios de Excelencia por no sé qué rescoldo vivo" (Azar, 1977: 118). La conexión francesa con lo libanés, el parentesco de credo (la cristiandad) y la educación religiosa que asegura el blanqueo, son dispuestos aquí en diálogos hipócritas y juegos lingüísticos churrierescos que desarman el entarimado ideológico previo a la Revolución.

Siguiendo como hilo conductor a la condesa (Musa y sus hijas aparecen apenas en el reparto), entramos en "El Salón Fumador", una pieza de estar de la condesa-especie de pastiche orientalista-, donde se relaja la élite empresarial de la ciudad, contando entre sus asiduos miembros a Mr. Guifford. Como si lo mexicano se trasvistiera de cierta indolencia y eroticidad provista por elementos extraños y que, sin embargo, se incluyen naturalmente en el escenario local.

Teniendo como telón de fondo "El Volcán Popocatépetl", se presentan dos tipos de discursos: un informe sobre la inmigración libanesa a México, escrito en francés (como sacado de un libro de Historia) y una voz en off, personal 
(como si fuera la del nieto), que insta al abuelo a ser un peregrino en el ancho mundo mexicano, bajo la imagen de mestizarse con su paisaje. Voz mexicana actual que pugna por vencer las resistencias de un Musa tradicional, apegado a códigos ancestrales y sólo con el referente francés: "Cuando regreses a tu hogar original lo encontrarás deshabitado y entonces tú serás el verdadero árbol de la noche triste" (Azar, 1977: 141). Aunque en este texto nunca se es muy conclusivo en cuanto a qué aspectos hay que renunciar para la marca mexicanalibanesa.

El cierre es cómico, pintoresco, contradictorio y vital. En un gesto de carnavalización, por cuanto aparece revuelto lo que a nivel normativo se debiera separar, escuchamos al General Marín Ochoa -cuyo nombre original es Tuntún Schuare- inaugurar una nueva cárcel en una edificación que fuera un antiguo convento de las Carmelitas, que tiene como apéndice el negocito de Musa Barba, denominado "El Puerto Libanés". Es como si lo libanés instituyera el orden del Bazar, descubriendo un rasgo caótico en la sociedad edilicia previa a los sucesos de 1910.

Libro experimental, donde compiten formas antiguas y nuevas de representación: el documento y la vanguardia, el realismo y su desfiguración farsesca, las personas y sus impostaciones. Libro biográfico, con marcas escondidas, que revela ciertas fracturas culturales en el diálogo intergeneracional. Libro migrante, que se desliza por distintos registros de habla y que tiene su centro en el festejo de la lengua mexicana, matriz que acoge el alma extranjera. Sin ella, pareciera indicarnos Héctor Azar, no es posible el viaje hacia los otros orígenes.

\section{LA RESTAURACIÓN DEL AURA}

Si ya constituye un desafío contar la historia de la llegada al mundo mexicano (un nuevo nacimiento), el despegue del bled; resulta más enigmático referir el regreso a la matriz original, más aún si quien lo hace nunca estuvo allí y sólo conoce esos paisajes a través de los relatos de sus padres y de la lectura de los textos de historia. Es el inquietante movimiento hacia otras coordenadas mentales, en busca de realizar un sueño: ser uno con todo lo procreado; en suma, ser feliz.

Es el caso de Carlos Martínez Assad, cuyos escritos nos devuelven a Líbano, cartografía desdoblada en un espacio desolado actual y uno prístino del pasado ${ }^{4}$.

${ }^{4}$ Carlos Martínez Assad es un distinguido sociólogo, académico de la Universidad Nacional Autónoma de México (UNAM), conocido por sus investigaciones sobre historia política y regional, 
Tanto su novela como luego su diario de viaje (mosaicos equivalentes, maderas del mismo cedro, árbol del Génesis), juegan a diseñar un punto mágico de convergencia entre lo antiguo y lo nuevo, sin por ello borrar el abismo entre Mito e Historia, Deseo y Realidad 5 .

En el verano, la tierra (Martínez Assad, 1994) es una novela alegórica, el relato de un viaje a Líbano de una pareja en el verano de 1975 justo en los prolegómenos de la guerra civil. José (mexicano, de linaje libanés) y Alina (hija de libanesa y de francés) parten desde París, la Ciudad Luz, hacia Damasco, para seguir viaje por tierra hacia el país natal (pasando por las ciudades sirias de Homs, Palmira, Hana y Alepo) y allí, en Líbano, visitar Trípoli, Mina, Beirut, Biblos y Baalbeck; para finalmente volver a Damasco vía Jordania.

Pareja incestuosa, se asemeja a la de los hermanos viajeros de los relatos bizantinos que realizaban un recorrido circular por las costas del Mediterráneo siguiendo un destino prefijado. Alina es misteriosa y alada (una idea, un fantasma), como aquellas figuras rioplatenses de aires parisinos que son Alejandra (la destruida por el dragón, de Sábato) y la Maga (la de los puentes de París, de Cortázar). José es un ser que deambula sin rumbo por el casco antiguo de la ciudad (alguien que busca un centro) y que es arrastrado por Alina a una aventura sublime y riesgosa. La partida es desde Francia, Padre adoptivo libanés, su marca colonial, su lejanía (el padre de Alina se aleja de ella, una vez muerta la madre libanesa).

La composición del relato es un montaje de tiempos y actores que van y vienen de Oriente a Occidente. En la primera parte, la historia de José y Alina en el París otoñal (que comparten con un grupo de estudiantes libaneses) se alterna con el relato de la experiencia migrante de un libanés (el abuelo de José) en tierras mexicanas. De un modo sucinto, se recubre la pequeña

que le han valido reconocimientos nacionales e internacionales. En la actualidad, es el actor cultural más relevante de la comunidad libanesa en México, por sus escritos y su labor de difusión del espíritu mexicano-libanés. Dirige Al Fannán, Asociación de Artistas e Intelectuales de Ascendencia Libanesa, que cuenta con una Gaceta Cultural.

${ }^{5}$ Una valiosa lectura de estas dos obras es emprendida por Daniela Zárate en su tesis de licenciatura sobre las voces mexicanas libanesas (Zárate, 2003). Entre otros aspectos, se destaca el parentesco que existe entre los espacios populares citadinos de México y Líbano, que permiten el deambular simbiótico del personaje. Es como si se estuviera en el mismo lugar (un doble origen): "El bullicio de los mercados invitan a la gente a que los visite. Los locales de frutas, carnes y hierbas pintan los colores el ambiente del lugar. Los gritos de los vendedores invitan a su clientela a conocer su mercancía" (Zárate, 2003: 74). Escenarios, entonces, intercambiables, a pesar de todo. Indicamos, de paso, que esta tesis revisa también materiales literarios escritos por Héctor Azar (aunque no Las tres primeras personas) y los textos poéticos de Jaime Sabines (proponiendo en su caso una integración sin escisiones).

Sobre la novela En el verano, la tierra, hay una nota reciente publicada por mí en la Revista de la Universidad de México (cf. Referencias). 
gesta de un libanés (cifra de una gesta colectiva), señalándose sus principales estancias: la partida, Veracruz, la peregrinación por diversos pueblos como buhonero, su instalación (en Huejutla) y las vicisitudes durante el largo periodo revolucionario. Mirada extranjera para un paisaje local, versión marginal de los inmigrantes sobre sucesos y costumbres (a manera de suplemento a la Historia Mexicana); pequeñas tragedias que no aparecen en la página pública (muerte cruel de su mujer en vías de parir, por ser víctimas de la persecución a los cristeros) y también pequeños logros económicos, gracias al comercio con las tropas revolucionarias. En fin, la esforzada vida de los primeros migrantes, cuyo relato en este caso culmina cuando la hija se casa con un funcionario público mexicano, que señala la entrada por la puerta ancha al país. Es, entonces, la palabra del abuelo (y de esa hija) la que impulsa a José a rastrear el tesoro perdido y devolverlo a los suyos. Así se inaugura el viaje de regreso, de Occidente (del viejo París, de la Nueva España) a Oriente (las escalas del Levante, los sitios sagrados nombrados en la Biblia).

La segunda parte, la más amplia, constituye el pasaje por las tierras del Levante, en estado de guerra virtual. Ahora bien, este viaje aparece interrumpido (iluminado) por una serie de apartados que incluyen leyendas, mitos y recuentos históricos y maravillosos sobre Líbano. Es como si la devastación del presente no lograra borrar las huellas prístinas del pasado. El desconcierto y desasosiego de José se hacen evidentes ante la contemplación de poblados abandonados, el lenguaje soez y agresivo en camiones (no hay maneras, se ha perdido la civilidad), la miseria de Chatila y Sabra, el tiroteo en las calles (Alina morirá en un siguiente viaje por una bala perdida, eclipsando cualquier utopía sobre una convivencia armónica). En este origen, el héroe aparece incómodo e incluso huérfano; no se reconoce allí: "Los cuartos que nos muestran son imposibles, apestan y la suciedad aparece por todas partes" (Martínez Assad, 1994: 62). Sólo de un modo intermitente, en su deambular por mezquitas, zocos, mercados y ruinas, la mirada del deseo transita; pero no logra instalarse en el corazón.

Es el sentimiento de lo siniestro - un heimlich, lo no familiar, según el principio freudiano-, la molestia por estar viendo algo inesperadamente desagradable. Es el regreso de lo reprimido, lo que en el relato del abuelo y de la madre aparecía suprimido; acaso la causa del abandono de ese lugar. ¿Un lugar, entonces, de la condena y de la culpa, la cara feroz del Padre, como en los espacios rulfianos?

No obstante, el viaje es otro. Detrás del viajero aparece una conciencia espiritual atemporal, que abre el espacio derruido al espacio de lo sublime, mediante la celebración de la historia milenaria de un pueblo a través de su repertorio oral y literario, que se irá intercalando para soportar la caída actual. Estos relatos originarios constituyen anclas, que permiten que la historia 
(occidental) regrese a sus inicios: de Roma a Biblos (donde se genera el alfabeto fenicio) y en la matriz, el cedro, árbol sagrado: “El cedro de Líbano estaba en el Paraíso', dice Ezequiel, y con sus maderas Noé construyó el Arca y en el monte Hermón vivieron Adán y Eva cuando, por desacatar la autoridad de Dios, buscaron refugio para ocultar su culpa" (Martínez Assad, 1994: 78).

A cada ciudad se le restaura su aura: Palmira es la novia del desierto, retratada en la reina Zenobia que extendió su imperio desde el Bósforo hasta el Nilo; Baalbeck es el sitio de la voluptuosa Astarté (antecedente de Artemisa) y Trípoli cristiano guarda en su seno a la bella Faride, cuyo sacrificio impidió que la ciudad fuese asolada por los mahometanos. La novela va acumulando, cual pequeños tesoros, historias de los comienzos de los tiempos, que siempre hemos anhelado escuchar: de la ninfa Tyrus y el color púrpura de sus ropas, teñidas con el molusco múrice; del abuelo de Mahoma y su descendencia; del joven Bata, cuyo corazón está resguardado en el milagroso árbol del cedro. Esta memoria de los orígenes aparece aunada a una memoria más reciente, que escenifica los dolores provocados por las persecuciones en la Modernidad, en testimonios bellos y tristes: una madre relatando los sucesos de 1860 (los drusos aniquilando impíamente a los maronitas), una refugiada kurda en Siria, luego de la matanza de los turcos en Anatolia en 1930.

En un epílogo, luego de concluido este viaje veraniego -que señala una "entrada a la madera", como anotaría Pablo Neruda, yendo a lo recóndito-, nos enteramos de la desgraciada muerte de Alina, quien formaba parte de una organización que luchaba por la paz en Líbano. Fin, entonces, a la utopía de la tolerancia religiosa y una sombra para el aura desplegada.

Escrita en 1994, los años que separan la escritura de los hechos narrados (1975) cubren los años de la guerra civil en Líbano. Novela alegórica (de la nación de orígenes fenicios), es también una novela biográfica, en cuanto está basada en los apuntes de viaje del autor en su visita a ese país en aquel verano. Si en la vivencia de ese viaje se experimentó la desazón (melancólica), por haberse extraviado una imagen incontaminada; en la escritura de esta novela se reinstala el deseo de seguir habitando en fronteras sin límites.

Este autor vuelve nuevamente a habitar esos parajes áuricos (semiderruidos) en Memoria de Líbano (Martínez Assad, 2003), diario que une dos viajes: el ya referido en la novela, del verano de 1975 y otro más reciente, en el otoño de 1998. Ahora es Carlos quien toma la palabra, primero como un doble de José y volviendo a sentir las dos caras de Jano de ese primer abordaje, y luego, en tiempos de mayor optimismo, sin otra sombra que la suya.

El texto consta de tres partes. "El camino a Líbano", que sigue la ruta ya conocida por nosotros, manteniéndose la desazón del protagonista: "Madre, 
salgo entristecido de Beirut" (Martínez Assad, 2003: 91). Como se observa, ahora el interlocutor manifiesto es la figura materna, espacio más personalizado; pero existe también otro lector apelado: aquél ávido por la historia no contada, por quien ansía una puesta al día de sus sueños, que ocurren en otro lugar.

El segundo viaje ocupa las dos siguientes partes: "Viaje en el tiempo" (donde aparece la voz de un historiador involucrado, que otorga su versión histórica sobre Líbano) y en especial, "Del eclipse al nuevo día", relato de su estancia, esta vez más ordenada y armónica (sin que el dejo de lo siniestro llegue a desaparecer del todo). Llega al bled el día del cumpleaños de su madre (como viéndola nacer o viéndose nacer en ella), en un gesto edípico que señala la insistencia del legado libanés en este mexicano. Si en 1975, el sujeto se constituye desde la desesperanza (en los dos libros: en la novela como melancolía y en el diario como un duelo), en el viaje de 1998 el sujeto siente que puede haber un nuevo despertar; de allí el título del capítulo. Esta vez existe una agenda, que reordena el sinsentido anterior: tiene acceso a los planos de la reconstrucción de Beirut, conversa con poetas, historiadores y sacerdotes maronitas, visita la casa de Gibrán Khalil Gibrán (en Becharre), el santuario de Nuestra Señora de Líbano en Hadissa y los monasterios de San Elisée (en Hasrum) y de San Antonio de Goshaya. Y finalmente, se encuentra con familiares -aunque esto, que podría haber sido un momento de iluminación, no tiene más brillo que los sucesos anteriores ${ }^{6}$.

Libro visual, cada paso está acompañado por un registro de fotos, huellas de un pasado que persiste como dato irrevocable, y también por un rosario de citas de viajeros, en que destacan Gérard de Nerval y Alphonse de Lamartine; miradas occidentales que rescatan la otredad desde el exotismo. Compartiendo los mismos materiales nobles que la novela -la celebración del Levante desde un repertorio de mitos y leyendas-, surge aquí con mayor énfasis la pasión del historiador por escribir otro tipo de relato histórico, un maravilloso libro de historia ilustrada, que logre animar el cuerpo derruido presente.

\footnotetext{
${ }^{6}$ Ensayando un libre diálogo con categorías freudianas -así como antes con la noción un heimlichkeit, lo siniestro, sentimiento de extrañeza ante la aparición en la pantalla de la conciencia de elementos reprimidos: pobreza y desamparo en el lugar del origen-, postulamos que en ambos textos existe una tensión entre la melancolía (la fijación a un objeto perdido, su búsqueda infructuosa en el presente) y el duelo (es decir, el desprendimiento del sujeto de esa fijación). El segundo libro y en él, el segundo viaje, de 1998, constituiría un trabajo de duelo: matar al muerto. ¿Cuál es el objeto perdido?: Un país donde conviven armónicamente diversos credos, un país actual espejo del pasado. Aún así, y aquí está el misterio y la maravilla del relato, sobre la melancolía y el duelo, y sobre el retorno de lo reprimido (que le señala al sujeto la miseria que subyace en la matriz) resurge el sentimiento de lo sublime, es decir, la capacidad del hombre para recrear una imagen prístina de su origen y su destino. Para las categorías freudianas (lo siniestro, la melancolía, el trabajo del duelo y el regreso de lo reprimido), cf. Laplanche y Pontalis, 1996.
} 
Las fichas del conocimiento histórico (reseñas de las ciudades, los recuentos de las Cruzadas, el corpus de relatos folklóricos, la misma historia actual de Líbano) son dispuestas en una pequeña enciclopedia para ser gozada y releída (como cuando éramos niños y Cortázar aprendía de El tesoro de la juventud y Borges de la Enciclopedia Británica, entendidas como ventanas al mundo). Cada página de esta Memoria de Líbano es un levantamiento arqueológico de las escalas del Levante, que desplaza nuestras coordenadas, inclinándonos hacia la regresión festiva que nos devuelve un mundo lejano, sobre el cual se funda nuestra cultura, la escritura e, incluso, el impulso (fenicio) por arribar a puertos desconocidos.

En este Diario se hace explícita la pregunta por nuestro lugar en la Historia de la Humanidad. Un mexicano de origen libanés nos señala: "porque necesitamos los recuerdos para saber quiénes somos" (Martínez Assad, 2003: 17). Nuestra identidad es entendida como una suma, un espacio virtual que es necesario ensanchar: "parte de esta historia [libanesa], madre, nos resulta cercana, y amplía nuestras identidades" (Martínez Assad, 2003: 151). En fin, no cabemos en un solo espacio, una sola lengua, un solo credo: "Hay que tener cuando menos dos mundos, porque, de lo contrario, se corre el riesgo de quedar encarcelado en uno de ellos" (Martínez Assad, 2003: 151). Es la recreación del espíritu mexicano-libanés, que bien puede ser un modelo para el espíritu americano, fundado en el diálogo cultural7. Quizás ahora entendamos mejor ese divagar del protagonista de la novela por parajes desconocidos, queriendo allí encontrar su sombra: “¿Acaso no puedo inventar y construir una vida no vivida?” (Martínez Assad, 1994: 114). La reinvención del Yo. Para eso escribimos, para ese leemos, para eso viajamos. Y ha sido así desde los comienzos de la Humanidad, comienzos migrantes.

\footnotetext{
${ }^{7}$ En el debate de las identidades culturales en una sociedad global, en el ámbito libanés es necesario tener presente el pensamiento de Amin Maalouf (melquita, hablante nativo árabe, que vive en Francia y escribe en francés), expresado por ejemplo en sus Identidades asesinas (Maalouf, 2001), donde rechaza la intolerancia religiosa como base de la identidad, proponiendo un sujeto abierto a sus diversos orígenes culturales, teniendo como centro rector una condición humana universal: "Una identidad que se percibiría como la suma de todas nuestras pertenencias, y en cuyo seno la pertenencia a la comunidad humana iría adquiriendo cada vez más importancia hasta convertirse un día en la principal, aunque sin anular por ello todas las demás particularidades" (Maalouf 2001: 109). Martínez Assad ha escrito un ensayo sobre este escritor, cuyo título hace clara mención a un espíritu menos estrecho de un sujeto adscrito a una nación y falsamente delimitado por su geografía y su lengua; ese título es: "Amin Maalouf, el forjador de leyendas. Su patria: el mundo" (Martínez Assad, 2004).
} 


\section{RAÍCES MIGRANTES}

Si alguien considera que la familia libanesa es una unidad afectiva y cultural indivisible, no importando el espacio geográfico ni la lengua; está en lo cierto. No obstante, al trasluz, es posible entrever la orfandad que conlleva cualquier proceso de migración; más aún si ocurre en un mundo donde los actores migrantes luchan por cambiar la Historia de la Humanidad.

Las hojas muertas (Jacobs, 1996) es la recreación otoñal, desde el borde de la vida, de un paraíso perdido, en torno a la figura del padre y de la casa libanesa ${ }^{8}$. Paraíso que es retrotraído a la infancia, para situarlos en los inicios de toda ilusión; y que finalmente se cumple sólo en el acto de la rememoración escrita, pues en la vida nunca se dio. El relato comienza así: "Ésta es la historia de papá, papá de todos nosotros" (Jacobs, 1996: 9). Quien habla es un coro infantil, los hijos e hijas, quienes buscan reivindicar la figura del padre para así colmar el vacío que siempre sintieron ante su pasiva presencia.

¿Desde qué tiempo hablan? ¿Por qué aparecen todos pegoteados, reunidos en un nosotros regresivo, voces adultas parapeteadas en gestos infantiles de búsqueda de reconocimiento, incluso, de infinito cariño? Escriben porque son huérfanos existenciales: no saben quién es su padre o por qué actúa como un sonámbulo. Y por ello, cual detectives en casa, comienzan la aventura de juntar las señas de ese personaje querible, que nació en Manhattan en 1909, se entusiasmó por el comunismo en el país equivocado, fue a Moscú en los años 30' y luego participó en la Guerra Civil Española, para volver a su país y pasar la Segunda Guerra encerrado en un campamento militar en Oklahoma en calidad de soldado raso (por sospechoso y rojillo). Y luego, en la gesta libanesa familiar, conocer a la mamá de nosotros, de vuelta de todos esos viajes, su prima segunda, y con su viejo Ford cruzar la frontera para instalarse en Ciudad de México en calidad de hotelero.

Vida para ser filmada, héroe de vuelta de mil batallas, ser utópico con mil historias que contar. Y sin embargo, ante nosotros, papá deambula por la casa como un fantasma, matando las horas con lecturas de almanaque. Esto, a nivel de los enunciados, es decir, de los hechos que ocurren; pero el libro adquiere su dimensión poética por su enunciación: la tarea de contar una historia a través de la creación de una voz comunitaria, que irá imbricando los tiempos, distinguiendo cortes (un antes, un después), para finalmente hacer converger el inicio con el final: se narra desde la madurez, los niños que fuimos, que

${ }^{8}$ Bárbara Jacobs, prestigiosa escritora mexicana, es autora de cuentos, novelas, ensayos y antologías literarias. Su libro Las hojas muertas, Premio Xavier Urrutia 1987, ha tenido varias reediciones, habiendo sido traducido al inglés, al portugués y al italiano. 
seguimos siendo hasta que demos una versión afectuosamente verosímil del papá de nosotros.

El relato distingue tres partes. La primera tiene como escenario la casa en México, cuando eran niños: es el triste después, de papá, cuando casi no hablaba. Son los tiempos del hotel "El hogar lejos del hogar", cuando supuestamente nosotros éramos felices. La parte dos es la reconstrucción de la biografía de papá, desde los pocos datos que nosotros ha logrado acumular, a través de la conversación familiar y de la escucha infantil: es el tiempo de antes, feliz, de papá, cuando era joven y viajaba (así lo desea nosotros). La última parte nos presenta a papá desde cuando deja la actividad del hotel (una jubilación temprana), trasladándose a vivir a la casa de sus suegros y su temprana vejez. Descubrimos que desde este tiempo subjetivo (la senectud) se enuncia la voz del relato. Desde el final de los días se vuelve a las preguntas e incertidumbres de la infancia, renaciendo el inmenso amor a papá, la nostalgia por los cuidados a media recibidos, la culpa por no haberlo acogido, pero también el resentimiento por haber sufrido una ausencia presente.

Más que nunca, aquí el texto es su entonación, la mimesis de una voz infantil afianzada en convenciones coloquiales y en una lógica de la contradicción que palpa el misterio paterno. Así, de una excursión de los padres a Europa, nosotros rescata el siguiente mensaje: "y mamá nos escribió que papá era un escéptico y que igual que Greta Garbo lo único que quería en el mundo era que lo dejaran en paz, en el caso de papá para poder leer en paz y recordar su vida de antes en paz aunque él antes fuera la guerra" (Jacobs, 1996: 39; cursiva nuestra). Frases coloquiales ("que me dejen en paz"), antagonismo léxico que deja entrever que algo anda mal: la guerra de antes, la paz actual... En este hilván sostenido por la repetición, se bosqueja a papá, una figura esquiva y misteriosa.

La biografía de papá, en el tiempo de antes, cuando era feliz es un ejercicio lúdico, nostálgico y obsesivo para hacer visible a papá ante sus hijos, la familia y el mundo. Contando con escasos datos (los olvidos y aprehensiones de la memoria migrante) y con el silencio del padre (no hay un testimonio ni historias al lado del fuego), esta biografía rodea los espacios de vida con palabras: "Entre esto y lo otro [:! ] el nuevo tiempo empezó a pasar [:!] y papá leía y se entretenía en Manhattan" (Jacobs, 1996: 65). ¿Cómo hablar de alguien marginado por la Historia oficial, y recluido en su casa, que sólo de vez en cuando se comunica con otra gente (tan extraña como él, viejos camaradas de la Brigada Lincoln que luchó en España) y que culmina enclaustrado en una pieza de la casa de sus suegros?

Nosotros ensaya un retrato afectivamente paródico de papá. Está el ímpetu infantil del escribiente colectivo, que lo hace aparecer como un Héroe, que 
comparte naturalmente con los hombres que cambiaron la Historia. Conoció a Paul Robeson y a Waldo Frank, y Arthur Rubinstein disfrutó mucho de su compañía; fue novio de la sobrina de Eisenstein y hubo un tiempo en que jugaba bridge con un general correligionario de Chiang-Kai-Chek. El cuento es ambiguo. ¿Los habrá conocido? Lo cierto es que nosotros nos indica que tenía amigos que le presentaron alguna vez a estos personajes (un amigo de un amigo), o que papá se topó con ellos fortuitamente (con Rubinstein en un tren). Ante la adversidad (sin trabajo y sin visa en Moscú, simple soldado raso privado de defender a su patria), la biografía recrea un personaje lleno de optimismo, locuaz -"en ese tiempo hablaba" (Jacobs, 1996: 69)-, dispuesto a soportar cualquier calamidad con buen talante: "pero papá no tomó nada de esto a mal porque todavía era joven y todo todavía era aprendizaje" (Jacobs, 1996: 78).

El ser abandonado por la historia, marginal y paria, aparece agigantado ante nuestros ojos, como los dibujos que hacen los niños de sus seres queridos, que son felices y que siempre nos protegerán. Esta imagen emotiva transparenta también la mirada paródica sobre el personaje, su doble faz: era alguien sin contactos importantes en este mundo, cuyas acciones pasaron inadvertidas a nivel público y que sufrió el desprecio de su país, por un idealismo acaso ingenuo y desmedido.

Un acápite final para enfocar a la familia, espacio de acogida natural de papá, que le permite un mínimo refugio ante el rechazo que sufre del mundo. $Y$ sin embargo, es también un espacio feble para él, por su marca migrante. El menor de tres hermanos, huérfano de padre a los 7 años de edad (don Rashil se vuelve a su tierra, quedando Mamá Salima, veinte años menor, a cargo del negocio de tapices en Manhattan), se casa con su prima luego de volver de España. Familia muy unida, mantiene sus vínculos afectivos a pesar de una cartografía migrante, que en el caso de Emile (nombre de papá, cuya voz directa sólo aparece en los epígrafes de los capítulos) lo tiende a alejar del nido familiar, como si éste fuera demasiado redondo. Los hermanos mayores viven en ciudades cercanas, Flint y Saginaw situadas en Michigan (ciudades hermanas) y Mamá Salima se cambia a Flint (donde está la hija) para seguir reunidos y viaja a Ciudad de México en fechas de festejos.

Para nosotros, el espacio familiar se reparte en un aqui y un allá-se habla de los "primos hermanos de allá"-, incluyéndose en el código familiar al menos dos lenguas (el inglés y el español y para la abuela, además, el árabe y el francés). Aun cuando existe cierta sinergia en materia de integración cultural, hay cortes evidentes en el ámbito de la nacionalidad (norteamericano/ mexicano, de orígenes libaneses) y del idioma (inglés/español). Papá habla en 
inglés y vive en un país foráneo, mientras que nosotros habla en español y va de visita donde sus tíos paternos al extranjero.

Familia libanesa extensa. Las hijas instaladas desde temprana edad en casa de sus abuelos maternos libaneses (¿por problemas económicos?), y luego papá refugiado en esa misma casa, como un niño. Familia trizada por los desplazamientos (una cartografía móvil) y seres que transitan por el mundo (como lo hicieran sus antepasados fenicios) y que vuelven a la casa libanesa, no importando el territorio. Y en el caso de Emile, con el agregado de que es un hogar para las almas migrantes: los parias, los olvidados, los soñadores. Luces y sombras: en la cuna del cedro, tronco patriarcal (madera sagrada), está el germen de la carencia y de la orfandad, que nos hace migrar.

\section{NUEVAS SEÑAS DE IDENTIDAD}

Ya sea desde el cuadro abultado de voces (el bazar mexicano-libanés de Azar), los apuntes de un viajero que se vuelve hacia los orígenes (las alegorías de la memoria en Martínez Assad) o del coro de voces infantiles ensayado desde la madurez (la biografía familiar en Jacobs); todas estas escrituras señalan una querencia antigua, diseñando para nosotros un horizonte cultural mexicanolibanés. Son las ansias de otredad americana, con vista al Levante.

La asimilación cultural es celebrada desde la lengua mexicana, sostén nutricio de los recién llegados en Las tres primeras personas. La otredad americana encuentra su forma en el eterno regreso hacia el Levante en los relatos En el verano, la tierra (donde el nieto deshace los pasos del abuelo inmigrante) y Memoria de Líbano (donde se viaja dos veces hacia el mismo lugar, en busca de lo perdido). En fin, la sensación de pérdida, la orfandad y el olvido del alma migrante aparecen en Las hojas muertas, cuya escritura señala el tronco familiar como el refugio sagrado de una comunidad dispersa.

\section{REFERENCIAS}

Azar, Héctor. 1977. Las tres primeras personas. México: Grijalbo.

Cánovas, Rodrigo. 2007. "Sobre En el verano, la tierra", en Revista de la Universidad de México, Nueva época 42, pp. 90-93.

Díaz, Martha y Macluf, Lourdes. 1997. De Líbano a México. Crónica de un pueblo emigrante. México D.F.: México: Centro Libanés y Edics. Gráfica, Creatividad y Diseño.

Eslabones. 1995. Revista semestral de estudios regionales 9 y 10, dedicados a Extranjeros en las Regiones. México: Sociedad Nacional de Estudios Regionales.

Jacobs, Bárbara. 1996. Las hojas muertas. México: Alfaguara. 
Jacobs, Patricia. 2000. Diccionario enciclopédico de mexicanos de origen libanés y de otros pueblos del Levante. México: Ediciones del Ermitaño, Minimalia.

Laplanche, Jean y J.-B. Pontalis. 1996. Diccionario de psicoanálisis. Barcelona: Paidós.

Marín-Guzmán, Roberto y Zéraoui, Zidane. 2003. Arab Immigration in Mexico in the Nineteenth and Twentieth Centuries. Assimilation and Arab Heritage. Austin/ Monterrey: Augustine Press, Instituto Tecnológico de Monterrey.

Maalouf, Amin. 2001. Identidades asesinas. Madrid: Alianza.

Martínez Assad, Carlos. 1994. En el verano, la tierra. México: Planeta. . 2003. Memoria de Líbano. México: Océano.

. 2004. "Amin Maalouf, el forjador de leyendas. Su patria, el mundo" en Blanco móvil 92 (subtitulado Voces de Líbano), dossier de 16 páginas incluido en la revista, con paginación independiente. México.

Nacif, Jorge. 1995. Crónicas de un inmigrante libanés en México. México: Instituto Cultural Mexicano Libanés.

Páez, Carmen. 1976. "Los libaneses en México: Asimilación de un grupo étnico". Tesis de Maestra en Ciencias Antropológicas con especialidad en Etnología. México: Escuela Nacional de Antropología.

Ramírez, Luis. 1994. Secretos de familia. Libaneses y élites empresariales en Yucatán. México: Conaculta.

Sabines, Jaime. 2003. Recuento de poemas 1950-1993. México: Joaquín Mortiz.

Salazar, Delia (coord.). 2006. Xenofobia y xenofilia en la historia de México siglos XIX yXX. México: SEGOB / Instituto Nacional de Migración / Centro de Estudios Migratorios.

Zárate, Daniela. 2003. Voces mexicanas libanesas: Carlos Martínez Assad, Héctor Azar y Jaime Sabines. Tesis de Licenciatura en Lengua y Literaturas Hispánicas. México: Universidad Nacional Autónoma de México, Facultad de Filosofía y Letras. 